\title{
Wastewater Reclamation in Major Jordanian Industries: A Viable Component of a Circular Economy
}

\author{
Motasem N. Saidan ${ }^{1, *(\mathbb{D}}$, Mohammad Al-Addous $\left.{ }^{2}{ }^{(}\right)$, Radwan A. Al-Weshah ${ }^{3}$, Ibrahim Obada ${ }^{4}$, \\ Malek Alkasrawi ${ }^{5}$ and Nesrine Barbana ${ }^{6}$ \\ 1 Department of Chemical Engineering, School of Engineering, The University of Jordan, \\ Amman 11942, Jordan \\ 2 Department of Energy Engineering, School of Natural Resources Engineering and Management, \\ German Jordanian University, Amman 11180, Jordan; mohammad.addous@gju.edu.jo \\ 3 Civil Engineering Department, School of Engineering, The University of Jordan, Amman 11942, Jordan; \\ weshah11@yahoo.com \\ 4 Ministry of Water and Irrigation, Amman 11181, Jordan; ibrahim.obadah@gmail.com \\ 5 Department of PS \& Chemical Engineering, University of Wisconsin, Stevens Point, WI 54481, USA; \\ malek.alkasrawi@uwsp.edu \\ 6 Department of Environmental Technology, Technische Universität Berlin, 10623 Berlin, Germany; \\ nesrine@campus.tu-berlin.de \\ * Correspondence: m.saidan@gmail.com or m.saidan@ju.edu.jo
}

Received: 13 March 2020; Accepted: 27 April 2020; Published: 30 April 2020

\begin{abstract}
Water scarcity remains the major looming challenge that is facing Jordan. Wastewater reclamation is considered as an alternative source of fresh water in semi-arid areas with water shortage or increased consumption. In the present study, the current status of wastewater reclamation and reuse in Jordan was analyzed considering 30 wastewater treatment plants (WWTPs). The assessment was based on the WWWTPs' treatment processes in Jordan, the flowrates scale, and the effluents' average total dissolved solid (TDS) contents. Accordingly, $60 \%$ of the WWTPs in Jordan used activated sludge as a treatment technology; 30 WWTPs were small scale $\left(<1 \times 10^{4} \mathrm{~m}^{3} /\right.$ day $)$; and a total of 17.932 million $\mathrm{m}^{3}$ treated wastewater had low TDS $(<1000 \mathrm{ppm})$ that generally can be used in industries with relatively minimal cost of treatment. Moreover, the analysis classified the 26 million $\mathrm{m}^{3}$ groundwater abstraction by major industries in Jordanian governorates. The results showed that the reclaimed wastewater can fully offset the industrial demand of fresh water in Amman, Zarqa, and Aqaba governorates. Hence, the environmental assessment showed positive impacts of reclaimed wastewater reuse scenario in terms of water depletion (saving of 72.55 million $\mathrm{m}^{3}$ groundwater per year) and climate change (17.683 million $\mathrm{kg} \mathrm{CO}_{2 \mathrm{Eq}}$ reduction). The energy recovery assessment in the small- and medium-scale WWTPs $\left(<10 \times 10^{4} \mathrm{~m}^{3} /\right.$ day $)$ revealed that generation of electricity by anaerobic sludge digestion equates potentially to an offset of $0.11-0.53 \mathrm{kWh} / \mathrm{m}^{3}$. Finally, several barriers and prospects were put forth to help the stakeholders when considering entering into an agreement to supply and/or reuse reclaimed water.
\end{abstract}

Keywords: reclaimed water; circular economy; anaerobic digestion; biogas; reuse; water pricing; water depletion; industrial sector

\section{Introduction}

Water is becoming a limited resource in terms of quantity and quality due to the growing global economy and population, accelerating urbanization, and climate change effects [1-3]. Water reuse 
has been employed as an alternative water supply in arid and semi-arid regions [4,5]. In this context, wastewater and water reclamation plays a vital role in sustainable water resource management and mainly in various application such as agricultural irrigation, industrial processes, aquaculture, and for any non-human contact utilization, etc. [5-8]. Moreover, reclaimed wastewater is a resource that can be continuously produced unaffected by climatic conditions $[9,10]$, especially in the Mediterranean region, one of the most vulnerable areas to climate change and with limited water resources [11-13].

However, the potential of recycling and reusing treated wastewater in a transition to a circular economy should be exploited thoroughly in arid and semi-arid areas, since it could synergize the wide adoption of water reuse as an alternate water supply [14-16].

\section{Wastewater Reclamation Overview in Jordan}

Jordan is classified as a semi-arid to arid country, with scarce water resources compared with other countries in the Middle East, and is ranked among the poorest countries in the world in terms of water availability [17-25]. Figure 1 shows the water resources in Jordan including locations of wastewater treatment plants (WWTPs). The Syria crisis is still adding strain on Jordan's economy and infrastructure and has put pressure on all sectors including water, municipal services, and electricity supply [26-34]. This problem is even more intense in areas with high population due to refugee influx that caused unsustainable over-exploitation of groundwater, and consequently led to increasing groundwater salinity and depleting resources (i.e., the water table was reduced by $5 \mathrm{~m}$ in areas like Dhuleil-Hallabat, area of the Amman-Zaraq basin, and tripled in salinity) [35].

Most of the published literature on water reuse in the Middle East focused on reclaimed wastewater uses in agricultural fields [36-40]. For instance, Hussain et al. (2019) reviewed 124 recent publications on the multiple aspects of safe use of treated wastewater for agriculture, landscape, and forestry and for non-conventional water resources management [40]. Moreover, it is also reported that approximately 20 million hectares of arable land worldwide is irrigated with wastewater [41].

Considering the water scarcity situation, Jordan has given top priority to the use of reclaimed wastewater in agriculture and industrial sectors [42-45], hence, the reuse of wastewater in agriculture has replaced freshwater resources, which were previously used for irrigation, allowing freshwater to be reallocated to the municipal sector where there is higher demand and quality water is needed for potable use. Despite of that, the agricultural sector accounts for $75 \%$ of all water consumption in Jordan and produces only $2 \%$ of the Gross Domestic Product (GDP) [46]. On the other hand, to reuse the reclaimed wastewater eco-efficiently in the industrial sector, most of the industrial facilities need to improve their wastewater management practices and upgrade their on-site treatment units to treat the wastewater before use [47].

The WWTPs play a vital role to decrease the environmental impacts of municipal and industrial discharges [48], while having an advanced (tertiary) treatment, the wastewater recycling and reuse can be promoted [49], as well as, enhancing the recovery of materials or energy [50]. Wastewater reclamation is one of the recommended solutions for the problem of water scarcity although the process may be complex, costly in terms of resources, and energy demanding depending on the quality of treated wastewater and the adopted technology for tertiary treatment [51]. However, shifting of the WWTP effluents from their application in agricultural irrigation to the industrial sector will require recognition of the fact that some agricultural activity would no longer have access to water for irrigation. Despite this, such a shift is recommended since most of the existing conventional treatment of WWTPs (mechanical chemical and biological treatment) does not eliminate emerging pollutants (i.e., pharmaceuticals and personal care products, hormones and steroids, persistent organic pollutants, etc.) from the wastewater, which can be induced into the food chain, subsequently causing adverse ecological and human health effects [52].

So far, wastewater reclamation and reuse in the context of water shortage in Jordan is not high, overall, whereas the potentiality of wastewater reuse is huge. The objectives of this paper are to compressively analyze the current status of wastewater reclamation and its reuse in major industries 
in Jordan, and to summarize the opportunities and the challenges of expanding wastewater reuse, and then to put forth prospects for future wastewater reclamation and reuse in Jordan.

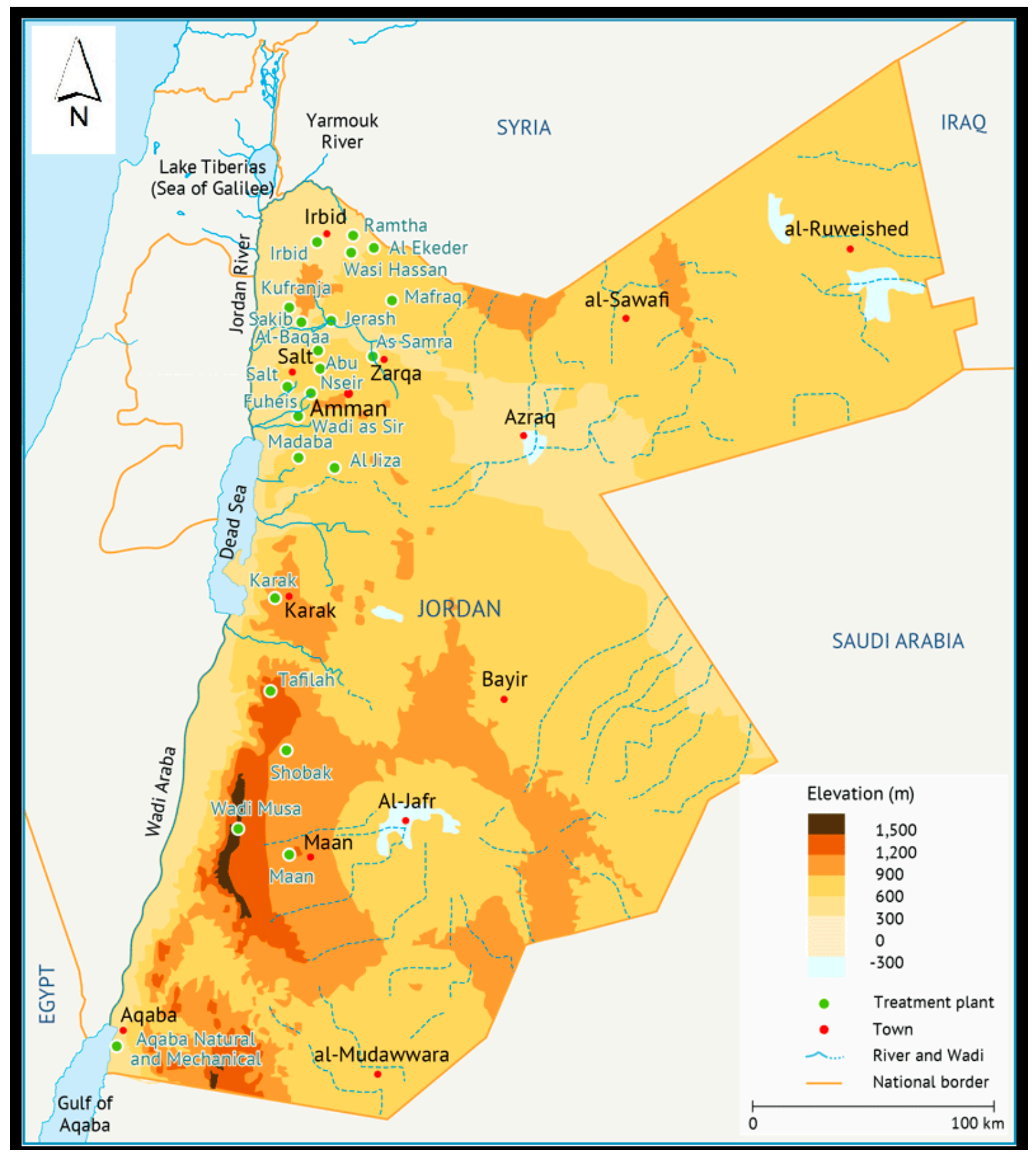

Figure 1. Water resources in Jordan.

\section{Materials and Methods}

\subsection{Wastewater Treatment Plants in Jordan}

Jordan has a fair operational capacity in wastewater treatment, although it is highly cost-intensive. The 34 central WWTPs are expected to treat 240 million $\mathrm{m}^{3}$ per year (MCM/year) by 2025 [18]. Increasing sanitation coverage is expensive, and the proposed shift in water sector expenditures from water supply to sanitation in 2011-2013 is a significant step toward increasing coverage. In 2013, collection costs amounted to JOD 47 million ( $1 \$$ is 0.71 Jordan Dinar (JOD)) and treatment costs to JOD 43.1 million [53]. Moreover, water and sanitation service costs are subsidized. Combined water and sewer bills amount 
to less than $0.92 \%$ of the total household annual expenditures. With Jordan's population expected to almost double by 2050, water demand will exceed the available water resources by more than 26\% [18].

Figure 2 shows the variety and distribution of 34 different processes in WWTPs in Jordan. The most widely used technologies are the activated sludge (AS) process with a share of $60 \%$. Followed by the wastewater stabilization pond (WSP) process with a share of $19 \%$. While the trickling filter (TF) and AS process, Membrane Bioreactor (MBR) and TF process, and oxidation sludge (OS) process were evenly having the same use share of $6 \%$, respectively. The TF process was the least used technology with a share of $3 \%$. Moreover, one of these WWTPs is of super-large scale $\left(>30 \times 10^{4} \mathrm{~m}^{3} /\right.$ day $), 4$ WWTPs are of medium scale $\left(1 \times 10^{4}-10 \times 10^{4} \mathrm{~m}^{3} /\right.$ day $)$, and 30 WWTPs are small scale $\left(<1 \times 10^{4} \mathrm{~m}^{3} /\right.$ day $)$, which are generally built in medium and small size cities and refugees camps.

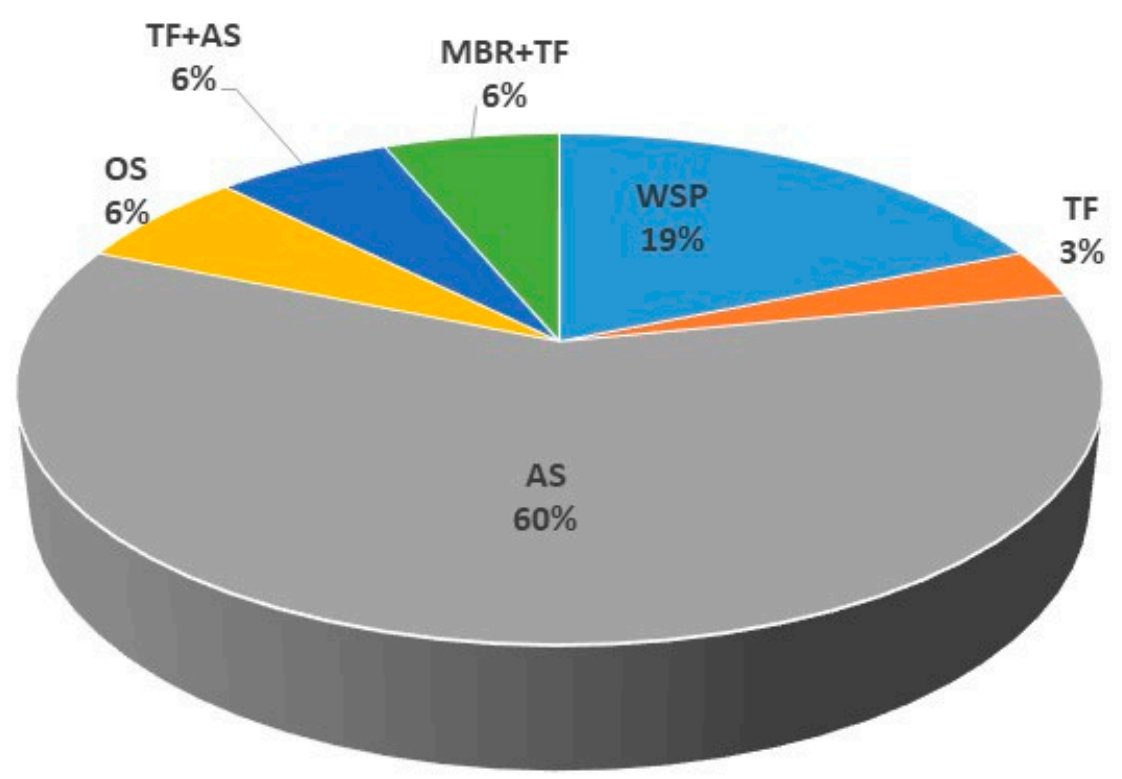

Figure 2. The variety and distribution of different processes in wastewater treatment plants (WWTPs) in Jordan. AS stands for activation sludge; OS is oxidation sludge; TF is trickling filter; WSP is wastewater stabilization pond; MBR + TF is Membrane Bioreactor and TF process; and TS + AS is trickling filter and activation sludge process.

\subsection{Data Gathering and Analysis}

The analysis carried out in the present study is divided into four main steps as illustrated in Figure 3, which shows the methodological approach to addressing the specific objectives of this study.

A desk study was carried out for the available baseline documents (i.e., unpublished, monthly progress reports, internal memos, and minutes of meetings) and other references for collecting the technical data. The data and information used in the present study were gathered via semi-structured interviews with key stakeholders in the water (Ministry of Water and Irrigation, Ministry of Agriculture, Ministry of Environment, etc.) and industrial sectors (Ministry of Trade and Industry, Chambers of Industry, etc.), and with international funding agencies (i.e., USAID, GIZ, etc.) involved in the ongoing projects targeting integrated water resource management in Jordan. In addition, qualitative and quantitative data and information have been derived from unpublished government reports.

Moreover, before the interviews, a brief session was hosted to probe respondents for greater clarity in answers and consistency in relation to the objectives of the questions.

Information obtained through the interviews was crosschecked with the objective to reassess gaps and divergences of information. 


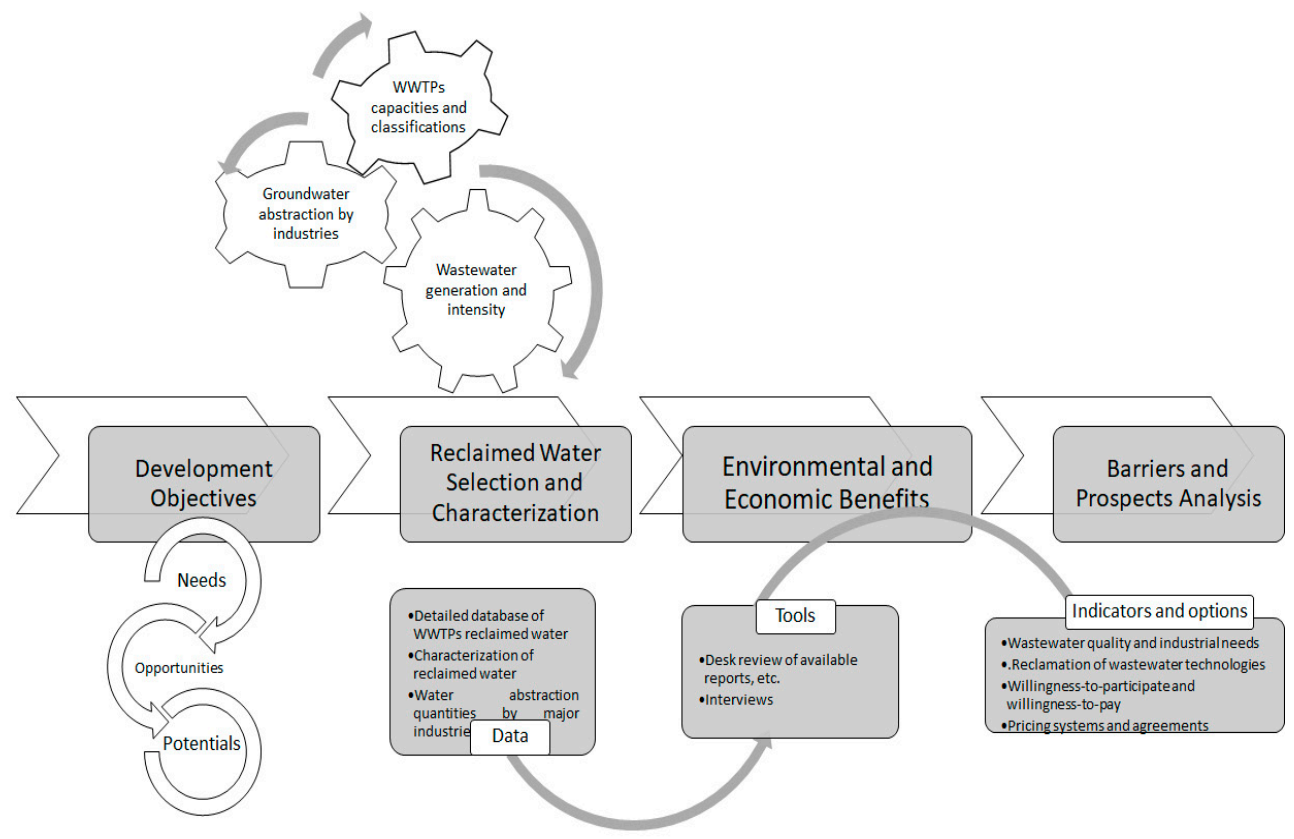

Figure 3. Diagram of the framework.

\section{Results and Discussion}

\subsection{Wastewater Reclamation: Current Capacity and Potential Reuse}

\subsubsection{Reclaimed Wastewater Production: Overview and Potentials}

Most of the WWTPs in Jordan provide secondary treatment with a variety of activated sludge processes followed by disinfection with chlorine. The exception is the Aqaba treatment facility, which provides tertiary filtration of the oxidized secondary effluent followed by ultraviolet disinfection and a chlorine residual. The total effluent of the wastewater flow from the WWTPs is around $166 \mathrm{million}^{3}$ based on data obtained from the Ministry of Water for the year 2018, as shown in Table 1.

The industrial sector mostly relies on fresh water, which could be used for domestic purposes. For instance, the industry uses 32.2 million $\mathrm{m}^{3}$ groundwater, 4.8 million $\mathrm{m}^{3}$ surface water, and $1.7 \mathrm{million}$ $\mathrm{m}^{3}$ of treated wastewater [18]. Thus, this provides a great opportunity for groundwater-to-recycled water substitution.

In the present study, the WWTP effluents were classified according to their average total dissolved solids contents (TDSs) as follows: $<1000$ ppm; $1000<$ TDS $<1500$; and $>1500$, based on wastewater analysis data (average data 2010-2016). Figure 4 shows the classification of WWTPs according to their effluents' TDS.

Table 1 shows the annual WWTP effluents' flow rate according to the TDS classifications. The first class (TDS < 1000 ppm), which relatively has the lowest TDS, can be reused several times in most industrial applications, especially in thermal units, cooling towers, etc. For instance, Aqaba recycled water, which has the lowest salinity among the WWTPs in Jordan (TDS $=587$ ppm), is most readily usable in industrial applications. So potentially, this class represents 9 WWTPs distributed in different locations in Jordan, as shown in Table 1, and, in total, 17.932 million $\mathrm{m}^{3}$ of treated wastewater of this class can be used directly with no or low cost of on-site treatment in the industrial sector depending on the fit-for-purpose water criteria.

However, the second class $(1000<$ TDS < 1500), which has medium TDS, has the highest annual effluent flow rate of 147.323 million $\mathrm{m}^{3}$ in total out of 18 WWTPs distributed in widely different locations in Jordan, as shown in Table 1. The most effluent wastewater flowrate in this class is generated from Al Samra WWTP with 117.1 million $\mathrm{m}^{3}$ per year by offering sanitation services to about two million in Amman and Zarqa governorates; the first and third most populated cities in 
Jordan, respectively [44,54]. With such large capacity and modern technology to ensure the highest purifications, Al Samra is considered as one of the largest plants in the region [40], which treats about $70.54 \%$ of total reclaimed wastewater in Jordan. This class represents 18 WWTPs distributed in different locations in Jordan, and, in total, 147.33 million $\mathrm{m}^{3}$ of treated wastewater of this class can be used with medium cost of some necessary modification in the plant process in the industrial sector depending on the fit-for-purpose water criteria.

The third class has a TDS $>1500$, the WWTP effluents in this class cannot be used without further intensive treatment such as: demineralization; blending with low-salinity water; and some change in the industrial process. This class represents three WWTPs with 0.788 million $\mathrm{m}^{3}$ of treated wastewater, as shown in Table 1 . Therefore, due to the high capital cost of investment and relatively expensive operating cost, this class is excluded from the present study analysis.

Table 1. Annual WWTP effluent flow rate according to the total dissolved solids (TDSs) classifications.

\begin{tabular}{|c|c|c|c|}
\hline TDS Classification & WWTP & $\begin{array}{l}\text { Effluent Flow Rate } \\
\text { (Million } \mathrm{m}^{3} / \text { year) }\end{array}$ & $\begin{array}{l}\text { Total Flowrate of Grouped } \\
\text { WWTPs (Million } \mathrm{m}^{3} / \text { year) }\end{array}$ \\
\hline \multirow{9}{*}{$<1000$ ppm } & Aqaba-Tertiary & 3.90 & \multirow{9}{*}{17.93} \\
\hline & Aqaba-Lagoon & 2.22 & \\
\hline & Wadi Essir & 1.71 & \\
\hline & Wadi Musa & 1.02 & \\
\hline & Salt & 3.19 & \\
\hline & Fuhis & 1.15 & \\
\hline & Abu Nusseir & 1.31 & \\
\hline & Madaba & 2.53 & \\
\hline & Ma'an & 0.92 & \\
\hline \multirow{18}{*}{$1000<$ TDS $<1500$} & Karak & 0.54 & \multirow{18}{*}{147.32} \\
\hline & Mafraq & 1.29 & \\
\hline & Mu'taa & 0.55 & \\
\hline & Wadi Hassan & 0.38 & \\
\hline & Al Samra & 117.10 & \\
\hline & Irbid & 3.10 & \\
\hline & Wadi Shalallah & 3.43 & \\
\hline & Kufranja & 1.25 & \\
\hline & Jeza & 0.29 & \\
\hline & South Amman & 4.72 & \\
\hline & Tafileh & 0.80 & \\
\hline & Wadi Arab & 4.98 & \\
\hline & Ain Albasha & 5.12 & \\
\hline & Al-Me'rad & 1.16 & \\
\hline & North Shouneh & 0.15 & \\
\hline & Tal-Almanttah & 0.15 & \\
\hline & Akeeder & 0.82 & \\
\hline & Ramtha & 1.50 & \\
\hline \multirow{3}{*}{$>1500$} & Jerash & 0.42 & \multirow{3}{*}{0.78} \\
\hline & Shobak & 0.05 & \\
\hline & Al Lujjon & 0.30 & \\
\hline
\end{tabular}

Excluding food and pharmaceutical industries, the total groundwater abstraction for industrial purposes was approximately 26 million $\mathrm{m}^{3}$ in Jordan in 2015 [55]. The major industries considered in the present study as the major groundwater abstracting industries are clarified in Table 2. Considering this, Figure 5 shows the total groundwater abstraction by major industries in Jordanian governorates, where the industries in Karak governorate were the most groundwater abstracting, with approximately 11.5 million $\mathrm{m}^{3}$ per year. Followed by the industries in $\mathrm{Ma}^{\prime}$ an $\left(4.38\right.$ million $\mathrm{m}^{3}$ per year). While the industries in Zarqa and Aqaba governorates were close to each other in terms of groundwater 
abstraction with 2.74 and 1.825 million $\mathrm{m}^{3}$ per year, respectively. The industries in the Capital Amman were the least groundwater abstracting with 0.611 million $\mathrm{m}^{3}$ per year.

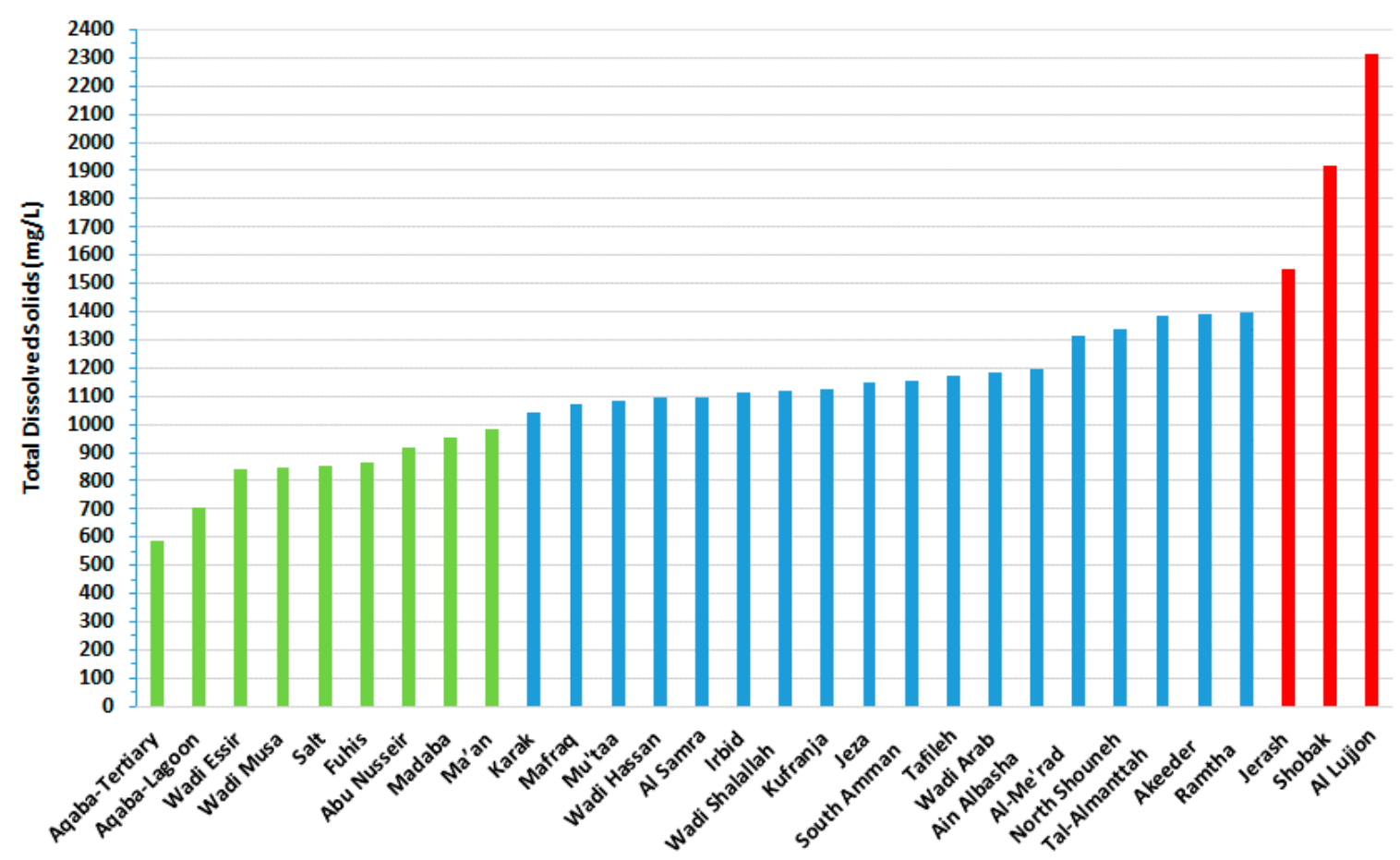

Figure 4. Classification of WWTPs according to their effluents' TDS.

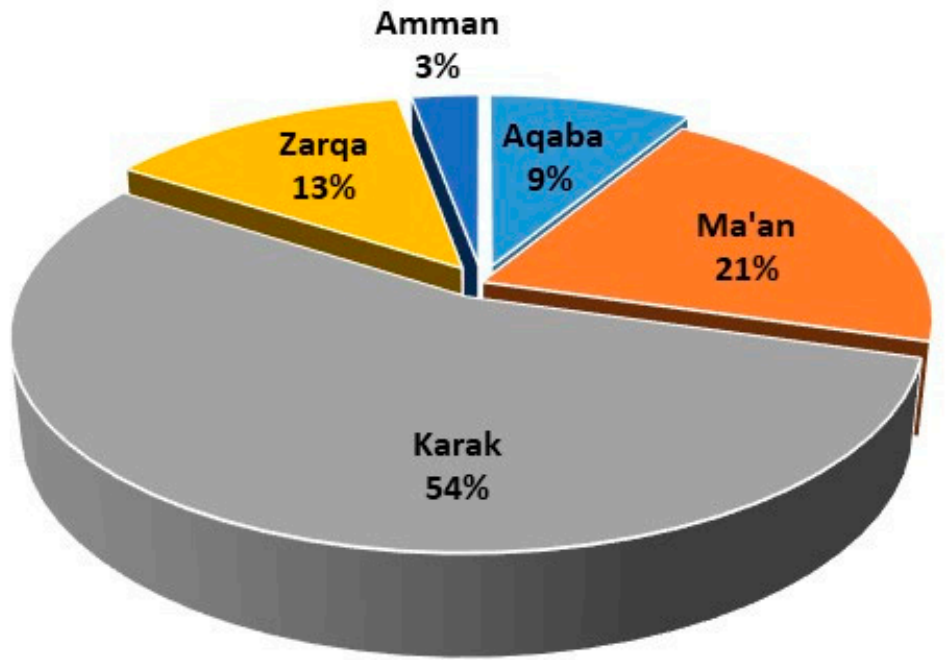

Figure 5. Percentages of total groundwater abstraction by major industries in Jordanian governorates.

Table 2. Major groundwater abstraction industries in Jordan according to governorates.

\begin{tabular}{cc}
\hline Governorate & Major Groundwater Abstraction Industries \\
\hline Amman & Cement, metals, concrete, paper and carton, etc. \\
Zarqa & Petroleum refinery, metals and pipes, paper and cardboard, thermal power and electricity plants, cement, etc. \\
Karak & Phosphate mines, potash, chemical fertilizers, cement, mining, etc. \\
Ma'an & Phosphate, cement, etc. \\
Aqaba & Phosphate, fertilizers, etc. \\
\hline
\end{tabular}

Hence, based on the data of first class and second class in Table 1, the potential reclaimed wastewater substitution in major industries in Jordanian governorates is shown in Figure 6. It is 
obvious that the reclaimed wastewater in Zarqa governorate can fully substitute the industrial demand of fresh water (Figure 6a) and the needs for irrigation of 3000 donums for 20-30 farmers adjacent to $\mathrm{Al}$ Samra WWTP as reported by Hussein (2018) [54] and Maldonado (2017) [44]. The full substitution of industrial demand is also noticed in both Amman and Aqaba governorates with 13.13- and 3.36-fold, respectively. However, the shortage of industrial demand substitution is significantly clear in both of Ma'an and Karak governorates with substitution amounts of 2.45 and 10.4 million $\mathrm{m}^{3}$ per year, respectively, as clearly shown in Figure 6b. Therefore, for the WWTPs in the governorates with a substitution factor less than one (mainly Ma'an and Karak governorates) it is preferable to prioritize their effluents (reclaimed wastewater) for irrigation use where applicable.

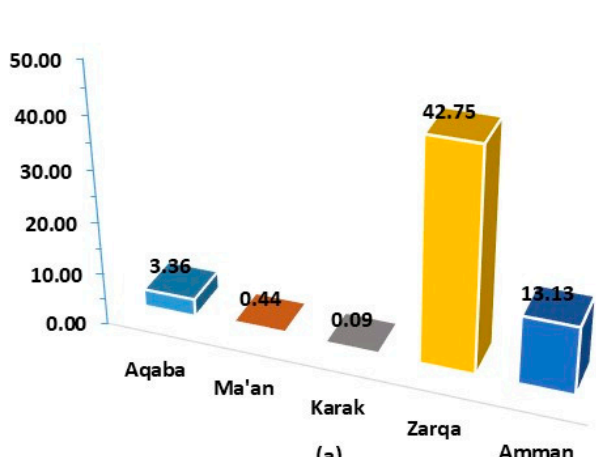

(a)

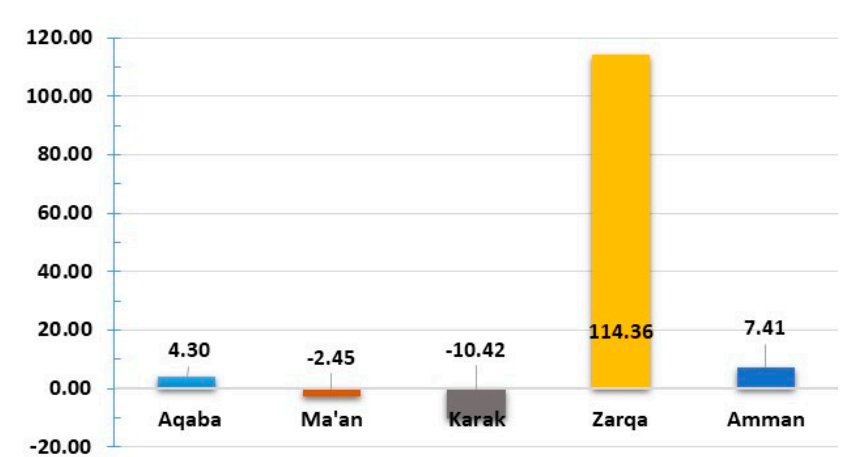

(b)

Figure 6. Reclaimed wastewater substitution in major industries in Jordanian governorates: (a) substitution factors, and (b) substitution amounts (million $\mathrm{m}^{3}$ per year).

Figure 7 shows the responses of the interviewed industries (17 samples from those shown in Table 2). It is drastically indicated that low TDS (water salinity) is the major requirement that was requested by $35 \%$ of the responses. Interestingly, the sample responses showed willingness to accept to replace the groundwater with reclaimed wastewater.

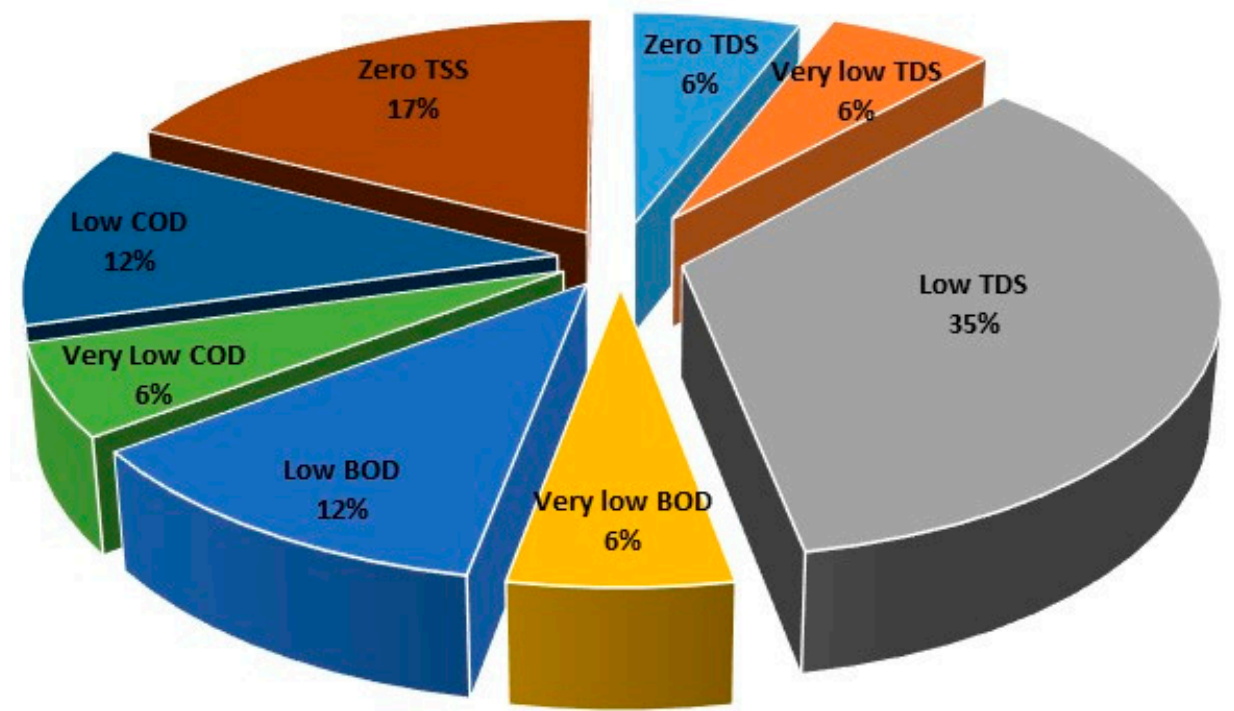

Figure 7. Responses of reclaimed wastewater quality requirements by the major industries.

However, $6 \%$ of the responses requested advanced treatment to receive very low values of TDS, biological oxygen demand (BOD), and chemical oxygen demand (COD). Zero total suspended solids (TSS) was requested by $17 \%$ of the responses, and this was mainly required for the cooling of power generators. 


\subsubsection{Environmental and Economic Benefits}

Pintilie et al. (2016) studied the life cycle assessment (LCA) of substituting fresh water with treated wastewater obtained from tertiary treatment and concluded that it does not lead to a substantial improvement of environmental impact for most of the indicators [48]. However, only water depletion (WD) and climate change (CC) were considered in the present study to compare the environmental impact between reclaimed wastewater reuse and no reuse scenarios. WD is recommended for water-stressed situations because a net saving of water from nature represents the most important effect of water reuse. The WD indicator values proposed by Pintilie et al. (2016) were considered in the present assessment as the following: $5.74 \times 10^{-4} \mathrm{~m}^{3}$ per $\mathrm{m}^{3}$ entering the whole system for the no reuse scenario, and $-4.39 \times 10^{-1} \mathrm{~m}^{3}$ per $\mathrm{m}^{3}$ entering the whole system for the reclaimed wastewater reuse scenario [48]. Negative values mean benefits to the environment, and positive values mean damages. Accordingly, using the data in Table 1, the annual wastewater effluent amounts (mainly the total flowrates of grouped WWTPs (million $\mathrm{m}^{3} /$ year)) of both TDS less than $1000 \mathrm{ppm}$ and $1000<$ TDS $<1500$ ppm were 17.93 and 147.33 million $\mathrm{m}^{3}$ per year, respectively. The sum of them is 165.26 million $\mathrm{m}^{3}$ per year, and using the aforementioned WD indicators, the analysis revealed that $94,860 \mathrm{~m}^{3}$ of fresh water are depleted for the scenario of no-reuse of reclaimed wastewater; however, 72.55 million $\mathrm{m}^{3}$ of water can be saved in reclaimed wastewater reuse in major industries in Jordan, as shown in Figure 8. Results of a similar tendency were founded in literature $[48,56]$.

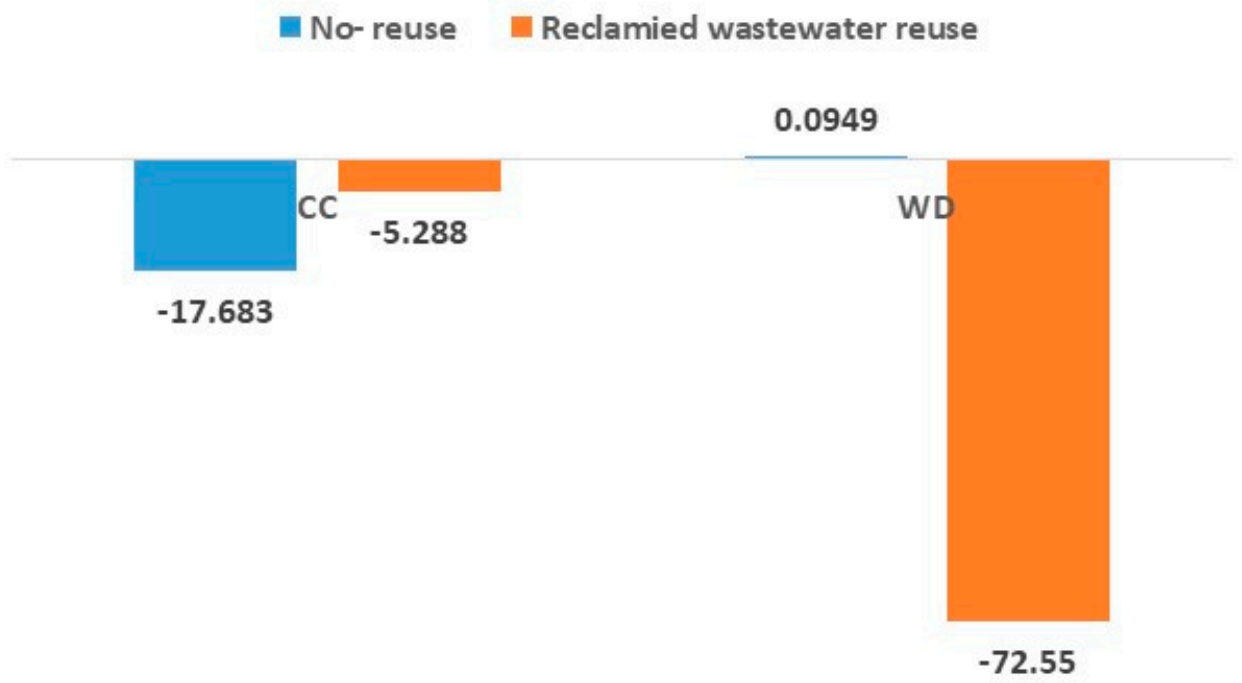

Figure 8. Water depletion (million $\mathrm{m}^{3}$ of water) and climate change (million $\mathrm{kg} \mathrm{CO}_{2 \mathrm{Eq}}$ ) analysis for both reclaimed wastewater reuse and no reuse scenarios (negative values mean benefits to the environment, and positive values mean damages).

The CC indicator values proposed by Pintilie et al. (2016) were considered as stated above [48]. The CC indicators were with negative values (indicates benefits to the environment) according to Pintilie et al. (2016) are the following: $-1.07 \times 10^{-1}$ and $-3.20 \times 10^{-2} \mathrm{~kg} \mathrm{CO}_{2 \mathrm{Eq}}$ per $\mathrm{m}^{3}$ reclaimed wastewater for both scenarios of reuse and no reuse, respectively [48]. Accordingly, using the data in Table 1, the annual wastewater effluent amounts (mainly the total flowrates of grouped WWTPs (million $\mathrm{m}^{3} /$ year)) of both TDS less than 1000 ppm and $1000<$ TDS < 1500 ppm were 17.93 and 147.33 million $\mathrm{m}^{3}$ per year, respectively. The sum of them is 165.26 million $\mathrm{m}^{3}$ per year, and using the aforementioned CC indicators, as shown in Figure 8, both scenarios showed beneficial impacts (negative values) to the environment in terms of climate change impacts. The no reuse scenario has relatively higher benefits with 17.683 million $\mathrm{kg} \mathrm{CO} 2 \mathrm{Eq}$ reduction compared to a 5.288 million $\mathrm{kg} \mathrm{CO} \mathrm{CO}_{2 \mathrm{Eq}}$ reduction for the reuse scenario. 
Normally, several factors influence the reclaimed wastewater provision and exploitation as a substitute [57,58]. According to the economic analysis of wastewater reclamation in Jordan, the difference between water price and reclaimed wastewater price plays a vital role in the willingness of the industries to accept the reclaimed wastewater as substitute. Therefore, for the low TDS $(<1000)$ reclaimed wastewater (Table 1 ), the average cost of one $\mathrm{m}^{3}$ of reclaimed wastewater is estimated at 0.55 JOD (including the pipeline installation, pumping electricity, and operation and naintenance (O\&M) costs), while the cost of fresh water is $1 \mathrm{JOD} / \mathrm{m}^{3}$. In this case, the reclaimed wastewater is competitive to some extent with regard to its price advantage. Moreover, based on experts' estimation, the environmental value of groundwater saved in the groundwater aquifer is $1.5 \mathrm{JOD} / \mathrm{m}^{3}$. Hence, the cost-benefit analysis of this case (water of TDS < 1000) is attractive for the consumer and the government.

While for reclaimed wastewater with TDS higher than $1000 \mathrm{ppm}$, a treatment is needed based on the application. Therefore, excluding the reuse of reclaimed in cement and concrete industries, the average cost of one $\mathrm{m}^{3}$ of reclaimed wastewater is estimated at 2 JOD (including treatment, pipeline installation, pumping electricity, and O\&M costs). It is worth mentioning that the long-distance pipelines from WWTPs to industrial zones and clusters, were the major cause for such costly per $\mathrm{m}^{3}$ water cost, especially in southern Jordan clusters. In order to overcome the hesitance of industries to reuse reclaimed wastewater when advanced treatment is required, subsidies by way of discounted cost of water should be provided in addition to fund allocation for capital cost coverage when on-site treatment is needed, as well as policy reforms to enhance the financial sustainability of the water sector.

\subsection{Energy Recovery from Wastewater Reclamation}

Wastewater treatment in WWTPs (mainly AS treatment process) requires around $0.38-2.74 \mathrm{kWh} / \mathrm{m}^{3}$ in Jordan, as shown in Figure 9. Additionally, $0.95-1.25 \mathrm{kWh} / \mathrm{m}^{3}$ is needed for wastewater as reported in literature $[59,60]$. The difference in energy use needed for wastewater reclamation and supply can be reduced by recovering organic energy during the wastewater treatment process [59]. Currently, only in the Al Samra WWTP, biogas production from sludge treatment is undertaken in Jordan. As shown in Figure 10, the two types of thickened sludge are mixed in two covered tanks of $98 \mathrm{~m}^{3}$ volume before being pumped and introduced in seven anaerobic digesters of a capacity of $15,900 \mathrm{~m}^{3}$ each. In the digesters, the sludge is mixed thoroughly by Cannon®mixers (Trevose, PA USA) using the recycled compressed biogas. The sludge stays for three weeks at $35^{\circ} \mathrm{C}$ in the digesters. Heating is done by hot water recovered from the cooling of the engines in a shell-and-tube heat exchanger. Through hydro energy and biogas production, the Al Samra WWTP has a potential energy recovery of $95 \%$ of its needs, only $5 \%$ is drawn from the national grid. Moreover, 300,000 tons of $\mathrm{CO}_{2}$ is saved per year through energy recovery and renewable energy utilization [61].

The introduction of anaerobic sludge digestion is generally expected to offset $25-50 \%$ of an aerobic wastewater treatment plant's energy needs $[59,63,64]$, however, based on WWTP data gathered in Jordan, having anaerobic sludge digestion in the small- and medium-scale WWTPs $\left(<10 \times 10^{4} \mathrm{~m}^{3} / \mathrm{day}\right)$ can potentially produce electricity that would equate to an offset of $0.11-0.53 \mathrm{kWh} / \mathrm{m}^{3}$. Consequently, this may help in reducing the costs of reclaimed wastewater reuse with further treatment requirements mainly for reclaimed wastewater with TDS higher than 1000 ppm as stated before.

However, energy produced from anaerobic sludge digestion can be feasibly increased by co-digestion with kitchen or other organic wastes [65-69]. Currently, the co-digestion is only applied at a laboratory scale in Jordan. Al-Addous et. al. (2019) evaluated the potential biogas production from the co-digestion of municipal food waste and wastewater sludge at a refugee camp. Accordingly, a possible ratio to start with is $60-80 \%$ organic waste, which can produce $21-65 \mathrm{~m}^{3}$ biogas ton $^{-1}$ of $^{-1}$ fresh matter [70].

Notwithstanding that co-digestion does not exist in Jordan yet, the anaerobic digestion systems tend to be well operated in Jordan (i.e., Al Samra WWTP). Hence, when co-digestion is utilized in Jordan, this will be a vital opportunity to make cost-effective use of existing facilities and improve sludge biogas potential [71-74]. 


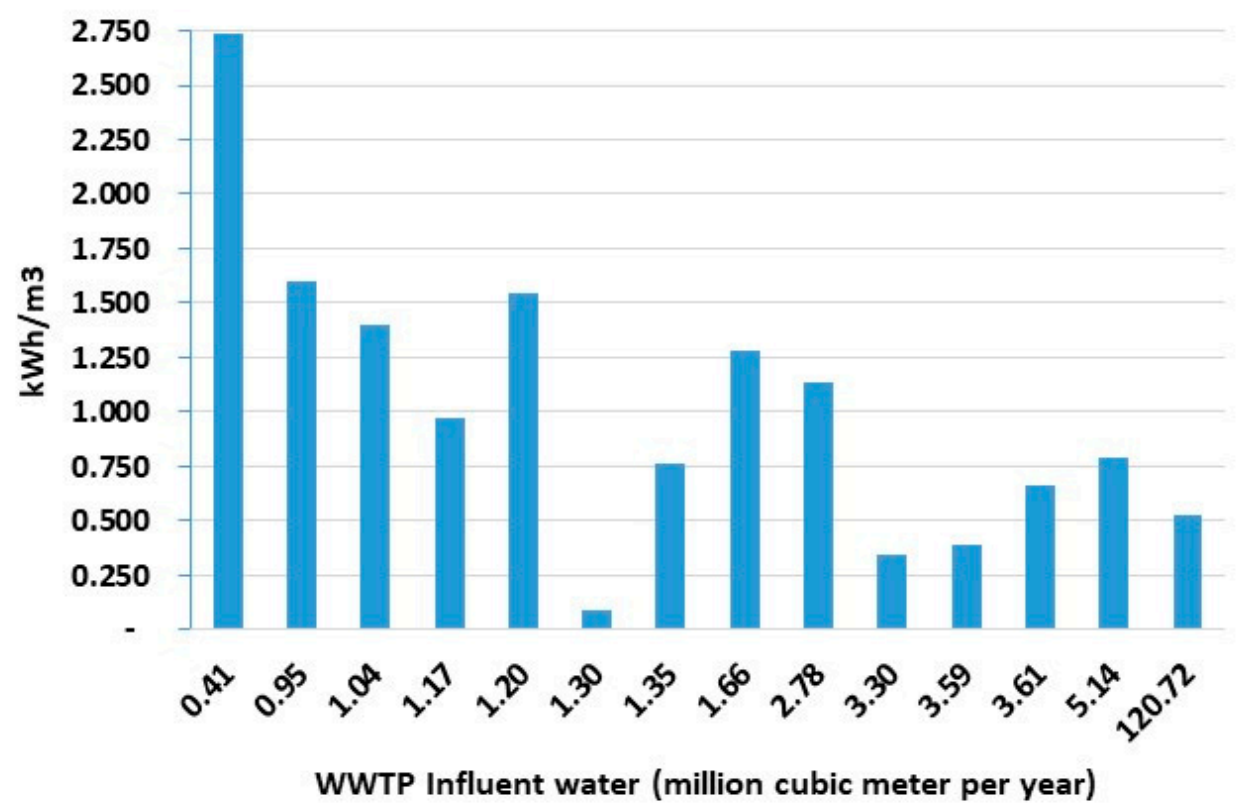

Figure 9. WWTPs' electricity consumption data for the activated sludge (AS) treatment process.

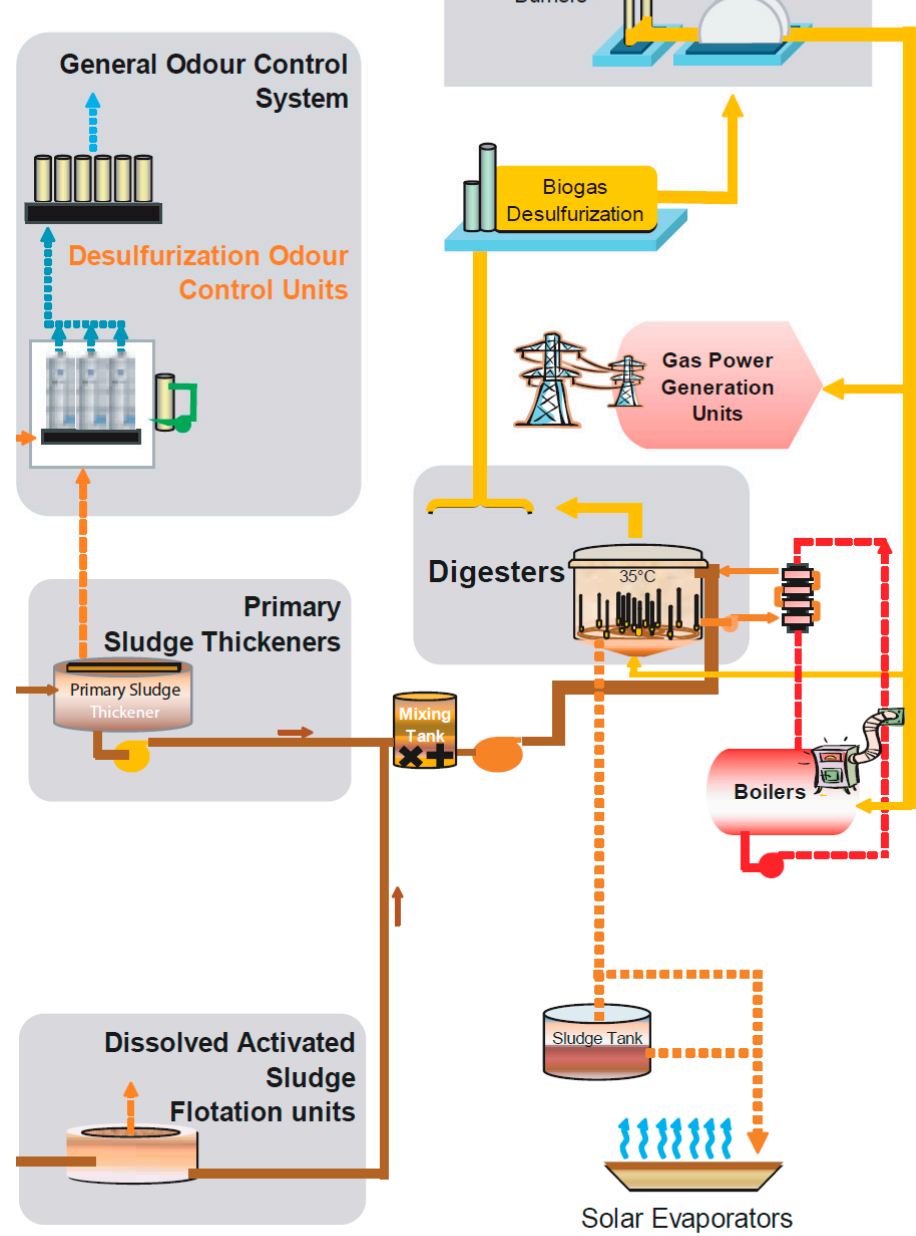

Figure 10. Biogas production in anaerobic digesters at the Al Samra WWTP [62]. 


\subsection{Reclaimed Wastewater Reuse: Barriers and Prospects}

\subsubsection{Reclaimed Wastewater Quality and Industrial Needs}

Industrial uses of reclaimed wastewater come in many different ways such as cooling-water, processing, and boiler feed water. Therefore, the process water requirements for water quality vary depending on the industry. Some of the concerns for industrial use of reclaimed wastewater are corrosion, scaling, and biological growth; however, these concerns are applicable to potable water as well. Most of cooling water is treated already to address these concerns. For instance, corrosion is a concern in cooling water no matter whether the facility uses potable water or reclaimed wastewater. Scaling from dissolved minerals such as calcium, magnesium, and phosphates can be controlled by monitoring and chemically treating the water to prevent scaling. Magnesium-phosphorus precipitation from sludge and the recovery of struvite after anaerobic sludge treatment process is conducted in order to prevent clogging in pumps and pipes in any further reuse applications [75-78]. Biological concerns can be addressed by adding chlorine to levels of $2.0 \mathrm{mg} / \mathrm{L}$ that will kill most microorganisms that causes corrosion or deposits in cooling systems [79].

To facilitate the use of recycled water in industrial applications, the information on the quality of the municipal recycled water should be provided and available to the industrial users. Moreover, opportunities to improve water quality for specific purposes, either by the supplier through additional treatment and/or source control, or the industrial user can improve treatment and control processes to levels specific to its process needs.

\subsubsection{Reclamation of Wastewater Technologies}

Lyu et al. (2016) discussed all advances in technology by which wastewater may be treated to meet the most stringent quality requirements and be used for any purposes desired [49]. For instance, the technologies applied in wastewater reuse include: (1) oxidants for disinfection purposes using sodium hypochlorite; ultraviolet radiation [80]; and ozone for high bactericidal disinfection [81] and the removal of 90-99\% for antibiotics and estrogens [82]; (2) biological treatments such as anaerobic, maturation ponds and constructed wetlands [83-85]; (3) physical separations such as membrane filtration for $81 \%$ removal of electroconductivity, $83 \%$ for $\mathrm{Na}^{+}$, and $80 \%$ for $\mathrm{Cl}^{-}$[86]; the removal of $95 \%$ of heavy metals [87]; the removal of $>89 \%$ of pharmaceuticals [88]; (4) electrochemical treatments to completely remove Escherichia coli [89-91]; as well as, (5) solar photocatalysis with $\mathrm{TiO}_{2}$ for $>90 \%$ removal of emerging pollutants (i.e., pharmaceuticals and personal care products) [92], and removals of $33 \%$ for Cd and $75 \%$ for Co [93].

\subsubsection{Reclaimed Wastewater Supply Continuity}

The industry demands a constant non-interrupted flow of reclaimed wastewater throughout the day [94]. In Jordan, although the reclaimed wastewater supply volumes vary diurnally and seasonally, its continuity is not so critical since WWTP effluents have relatively uninterruptable higher flows than the demand flows needed by the nearby main industries. It is noteworthy that flow equalization and water conveying capacities should be investigated to match the supplies with the demands and vice versa [95].

\subsubsection{Willingness to Participate and Willingness to Pay}

As deduced based on the results of these interviews, most of main industries considered in the present study expressed a positive stance toward reclaimed wastewater reuse, while they are willing to pay a significantly less amount of money than they already pay, for freshwater. Therefore, a comprehensive survey about the willingness of the industrial sector to switch to the use of reclaimed wastewater instead of groundwater is of high significance. Such surveys will help in providing more accurate data for the financial evaluation of the recycled water service and a basis for negotiation with the industries. 
Factors that influence industrial user's 'willingness to pay' for reclaimed wastewater include: (1) price of alternative water sources (i.e., potable, surface water, and groundwater supplies); (2) perception of the scarcity of alternative sources; (3) capital and operating costs of switching to reclaimed wastewater supply; (4) reclaimed wastewater quality, quantity, and levels of service and reliability of supply.

\subsubsection{Pricing Systems}

A range of pricing systems for reclaimed wastewater can be proposed in Jordan and assessed on a win-win situation. The pricing systems can be employed alone or in combination [96], which are, but not limited to: (1) A usage fee scheme in which the industries finance the infrastructure installation, and then the usage charge offsets the supply cost of the reclaimed wastewater. For instance, such type of pricing was adopted in 2003 by the Australian government under the national water reform process [97]. (2) A connection fee which is a once-off contribution toward the cost of infrastructure needed to deliver reclaimed wastewater to the industry's delivery point. This fee may be subject to negotiation between the supplier and the industries to agree on a financial arrangement where both parties may fully or partially cover the fee of the actual work to deliver the reclaimed water to the delivery point. (3) A flat fee regardless of use ("take or pay" arrangement). For instance, regardless of actual use, the industries are obliged to pay for $75-100 \%$ of the contracted recycled water volume, and for all water consumed by the industries above the contracted level. Although this pricing scheme provides the WWTPs with guaranteed income that sustains the financials of running the scheme, it may encourage overuse of reclaimed wastewater by the industry and improper discharges to the environment.

\subsubsection{Reclaimed Wastewater Agreements}

Specific reclaimed wastewater guidelines are important in managing the supply and use of reclaimed wastewater particularly in relation to quantity and quality [98]. Through the agreement negotiations between the supplier of reclaimed wastewater and the customers (i.e., industries). Wherein, the parties agree to a set of obligations and responsibilities under which the reclaimed wastewater reuse scheme will operate [99]. Key issues that reclaimed wastewater agreements should cover include: (a) price, quantity, and quality of reclaimed wastewater; (b) security of the reclaimed wastewater supply; (c) measures to identify, allocate, and manage risks and ensure safe use of reclaimed wastewater; (d) liabilities and insurance for potential damages caused by supply and use; and (e) compliance with legislative and common law requirements.

\section{Conclusions}

The following findings can be concluded in the present study:

- Jordan is classified as a semi-arid to arid country and is ranked among the poorest countries in the world in terms of water availability. Therefore, reclaimed wastewater reuse has been driven as an alternative water supply in such looming challenges of water scarcity. For instance, a total of 26 million $\mathrm{m}^{3}$ of groundwater abstraction is exploited annually for industrial purposes.

- In the present study, the 34 processes in WWTPs in Jordan were assessed in terms of their treatment processes, scale, and effluent TDS. The most widely used technologies are AS (60\%) and WSP (19\%), while the TF and AS process, MBR and TF process, and OS processes were had an even use share of $6 \%$ each. Moreover, 30 WWTPs were classified as small scale $\left(<1 \times 10^{4} \mathrm{~m}^{3} /\right.$ day $)$, which were generally built in medium- and small-size cities and refugee camps. Moreover, the analysis showed that 17.932 million $\mathrm{m}^{3}$ of treated wastewater has low TDS $<1000$ ppm and can be reused several times in most industrial applications, especially in thermal units, cooling towers, etc. However, highest annual effluents flow rate of 147.323 million $\mathrm{m}^{3}$ in total out of 18 WWTPs distributed in widely different locations in Jordan have $1000<$ TDS $<1500$, which can be used with medium cost depending on the fit-for-purpose water criteria. 
- Full substitution of industrial demand by reclaimed wastewater reuse can be achieved in both Amman and Aqaba governorates with 13.13- and 3.36-fold, respectively. However, the shortage of industrial demand substitution by reclaimed wastewater is significantly clear in both of Ma'an and Karak governorates with substitution amounts of 2.45 and 10.4 million $\mathrm{m}^{3}$ per year, respectively.

- The environmental assessment showed positive impacts of reclaimed wastewater reuse scenario in terms of water depletion (saving of 72.55 million $\mathrm{m}^{3}$ of groundwater per year) and climate change (17.683 million $\mathrm{kg} \mathrm{CO} 2 \mathrm{Eq}$ reduction).

- From circular economic perspective, and based on WWTP data gathered in Jordan, having anaerobic sludge digestion in the small- and medium-scale WWTPs $\left(<10 \times 10^{4} \mathrm{~m}^{3} /\right.$ day $)$ can potentially produce electricity that would equate to an offset of $0.11-0.53 \mathrm{kWh} / \mathrm{m}^{3}$. Consequently, this may help in reducing the costs of reclaimed wastewater reuse with further treatment requirements mainly for reclaimed wastewater with TDS higher than 1000 ppm as stated before.

- It is recommended in the present study that reclaimed wastewater agreement negotiations should be promoted between the supplier of reclaimed wastewater and the customers (i.e., industries). Moreover, indicators such as willingness to participate and willingness to pay need to be significantly determined in order to reach a win-win scheme of reclaimed water pricing model.

Author Contributions: Conceptualization, M.N.S. and I.O.; Methodology, M.N.S., I.O., and R.A.A.-W.; Formal analysis, M.N.S., M.A., M.A.-A., N.B., and I.O.; Investigation, M.N.S., R.A.A.-W., and I.O.; Resources, M.N.S. and I.O.; Writing—original draft preparation, M.N.S., M.A., M.A.-A., and I.O.; Writing—review and editing, M.N.S. and R.A.A.-W.; Project administration, M.N.S., N.B. and I.O. All authors have read and agreed to the published version of the manuscript.

Funding: This research received no external funding.

Acknowledgments: The corresponding author does acknowledge with gratitude the University of Jordan for granting him sabbatical assistance to undertake this research study. The authors also thank the anonymous reviewers and the editor of the journal for their constructive feedback.

Conflicts of Interest: The authors declare no conflict of interest.

\section{References}

1. Forslund, A.; Malm Renöfält, B.; Barchiesi, S.; Cross, K.; Davidson, S.; Ferrel, T.; Korsgaard, L.; Krchnak, K.; McClain, M.; Meijer, K.; et al. Securing Water for Ecosystems and Human Well-being: The Importance of Environmental Flows (Swedish Water House Report 24); Swedish International Water Institute: Stockholm, Sweden, 2009.

2. Roccaro, P.; Verlicchi, P. Wastewater and reuse. Curr. Opin. Environ. Sci. Health 2018, 2, 61-63. [CrossRef]

3. Sun, Y.; Chen, Z.; Wu, G.; Wu, Q.; Zhang, F.; Niu, Z.; Hu, H.Y. Characteristics of water quality of municipal wastewater treatment plants in China: Implications for resources utilization and management. J. Clean. Prod. 2016, 131, 1-9. [CrossRef]

4. Shannon, M.; Bohn, P.W.; Elimelech, M.; Georgiadis, J.G.; Mariñas, B.J.; Mayes, A.M. Science and technology for water purification in the coming decades. Nature 2008, 452, 301-310. [CrossRef] [PubMed]

5. Akhoundi, A.; Nazif, S. Sustainability assessment of wastewater reuse alternatives using the evidential reasoning approach. J. Clean. Prod. 2018, 195, 1350-1376. [CrossRef]

6. Chen, W.; Geng, Y.; Dong, H.; Tian, X.; Zhong, S.; Wu, Q.; Li, S. An emergy accounting based regional sustainability evaluation: A case of Qinghai in China. Ecol. Indic. 2018, 88, 152-160. [CrossRef]

7. Yan, H.; Wu, F.; Dong, L. Influence of a large urban park on the local urban thermal environment. Sci. Total Environ. 2018, 622, 882-891. [CrossRef]

8. Zhou, Z.; Zhang, X.; Dong, W. Fuzzy comprehensive evaluation for safety guarantee system of reclaimed water quality. Procedia Environ. Sci. 2013, 18, 227-235. [CrossRef]

9. Ait-Mouheb, N.; Bahri, A.; Thayer, B.B.; Benyahia, B.; Bourrié, G.; Cherki, B.; Condom, N.; Declercq, R.; Gunes, A.; Héran, M.; et al. The reuse of reclaimed water for irrigation around the Mediterranean Rim: A step towards a more virtuous cycle? Reg. Environ. Change 2018, 8, 693-705. [CrossRef]

10. Licciardello, F.; Milani, M.; Consoli, S.; Pappalardo, N.; Barbagallo, S.; Cirelli, G. Wastewater tertiary treatment options to match reuse standards in agriculture. Agric. Water Manag. 2018, 210, 232-242. [CrossRef] 
11. Collet, L.; Denis, R.; Borrell Estupina, V.; Dezetter, A.; Servat, E. Water supply sustainability and adaptation strategies under anthropogenic and climatic changes of a meso-scale Mediterranean catchment. Sci. Total Environ. 2015, 536, 589-602. [CrossRef]

12. La Jeunesse, I.; Cirelli, C.; Aubin, D.; Larrue, C.; Sellami, H.; Afifi, S.; Bellin, A.; Benabdallah, S.; Bird, D.N.; Deidda, R.; et al. Is climate change a threat for water uses in the Mediterranean region? Results from a survey at local scale. Sci. Total Environ. 2016, 543, 981-996. [CrossRef] [PubMed]

13. European Environmental Agency. Climate Change, Impacts and Vulnerably in Europe-An Indicator-Based Report; European Environmental Agency (2012) EEA report no 12/2012; European Environmental Agency: København, Denmark, 2012.

14. Voulvoulis, K. Water reuse from a circular economy perspective and potential risks from an unregulated approach. Curr. Opin. Environ. Sci. Health 2018, 2, 32-45. [CrossRef]

15. Coats, E.R.; Wilson, P.I. Toward nucleating the concept of the water resource recovery facility (WRRF): Perspective from the principal actors. Environ. Sci. Technol. 2017, 51, 4158-4164. [CrossRef]

16. Sgroi, M.; Vagliasindi, F.G.A.; Roccaro, P. Feasibility, sustainability and circular economy concepts in water reuse. Curr. Opin. Environ. Sci. Health 2018, 2, 20-25. [CrossRef]

17. Matouq, M.; El Hasan, T.; Al Bilbisi, H.; Abdelhadi, M.; Hindiyeh, M.; Eslaiman, S.; Duheisat, S. The climate change implication on Jordan: A case study using GIS and artificial neural networks for weather casting. J. Sci. Taibah Univ. 2013, 7, 44-55. [CrossRef]

18. Ministry of Water and Irrigation. Jordan's Water Strategy 2016-2025; Ministry of Water and Irrigation: Amman, Jordan, 2016.

19. Aboelnga, H.; Saidan, M.; Al-Weshah, R.; Sturm, M.; Ribbe, L.; Frechen, F.B. Component analysis for optimal leakage management in Madaba, Jordan. J. Water Supply Res. Technol. 2018, 67, 384-396. [CrossRef]

20. Saidan, M.N.; Al-Weshah, R.A.; Obada, I. Potential Rainwater Harvesting: Adaptation Measure for Urban Areas in Jordan. Am. Water Works Assoc. 2015, 107, 594-602. [CrossRef]

21. Al-Weshah, R.; Saidan, M.; Al-Omari, A. Environmental ethics as a tool for sustainable water resource management. Am. Water Works Assoc. 2016, 108, 175-181. [CrossRef]

22. Al-Awad, T.K.; Saidan, M.N.; Gareau, B.J. Halon management and ozone-depleting substances control in Jordan. Int. Environ. Agreem. 2018, 18, 391-408. [CrossRef]

23. Aldayyat, E.; Saidan, M.N.; Abu Saleh, M.A.; Hamdan, S.; Linton, C. Solid Waste Management in Jordan: Impacts and Analysis. J. Chem. Technol. Metall. 2019, 54, 454-462.

24. Alrabie, K.; Saidan, M.N. A preliminary solar-hydrogen system for Jordan: Impacts assessment and scenarios analysis. Int. J. Hydrog. Energy 2018, 43, 9211-9223. [CrossRef]

25. Khasawneh, H.; Saidan, M.; Al-Addous, M. Utilization of hydrogen as clean energy resource in chlor-alkali process. Energy Explor. Exploit. 2019, 37, 1053-1072. [CrossRef]

26. Saidan, M. Cross-sectional survey of non-hazardous waste composition and quantities in industrial sector and potential recycling in Jordan. Environ. Nanotech. Monitor. Manag. 2019, 12, 100227. [CrossRef]

27. Al-Addous, M.; Saidan, M.; Bdour, M.; Dalalah, Z.; Albatayneh, A.; Class, C.B. Key aspects and feasibility assessment of a proposed wind farm in Jordan. Int. J. Low-Carbon Technol. 2019. [CrossRef]

28. Saidan, M.N.; Abu Drais, A.; Linton, C.; Hamdan, S. Solid waste Characterization and recycling in Syrian refugees hosting communities in Jordan. In Waste Management in MENA Regions, 1st ed.; Negm, A.M., Noama, E., Eds.; Earth and Environmental Sciences Series, Applied Environmental Science and Engineering for a Sustainable Future; Springer International Publishing AG, Part of Springer Nature: Cham, Switzerland, 2019.

29. Saidan, M.N.; Ansour, L.M.; Saidan, H. Management of Plastic Bags Waste: An Assessment of Scenarios in Jordan. J. Chem. Technol. Metall. 2017, 52, 148-154.

30. Hararah, M.A.; Saidan, M.N.; Alhamamre, Z.; Abu-Jrai, A.M.; Alsawair, J.; Damra, R.A. The PCDD/PCDF emission inventory in Jordan: Aqaba city. J. Chem. Technol. Metall. 2016, 51, 112-120.

31. Saidan, M.; Tarawneh, A. Estimation of potential E-waste generation in Jordan. Ekoloji 2015, $24,60-64$. [CrossRef]

32. Tarawneh, A.; Saidan, M. Households awareness, behaviors, and willingness to participate in E-waste management in Jordan. Int. J. Ecosys 2013, 3, 124-131.

33. Saidan, M.; Khasawneh, H.J.; Tayyem, M.; Hawari, M. Getting energy from poultry waste in Jordan: Cleaner production approach. J. Chem. Technol. Metall. 2017, 52, 595-601. 
34. Hindiyeh, M.; Altalafha, T.; Al-Naerat, M.; Saidan, H.; Al-Salaymeh, A.; Sbeinati, L.A.; Saidan, M.N. Process modification of pharmaceutical tablet manufacturing operations: An Ecoefficiency approach. Processes 2018, 6, 15. [CrossRef]

35. METAP-World Bank. Water Quality Management Jordan-World Bank. Available online: http://siteresources. worldbank.org/EXTMETAP/Resources/WQM.JordanP.pdf (accessed on 2 October 2019).

36. Salahat, M.A.; Al-Qinna, M.I.; Badran, R.A. Potential of Treated Wastewater Usage for Adaptation to Climate Change: Jordan as a Success Story. In Water Resources in Arid Areas: The Way Forward. Springer Water; Abdalla, O., Kacimov, A., Chen, M., Al-Maktoumi, A., Al-Hosni, T., Clark, I., Eds.; Springer: Cham, Switzerland, 2017.

37. Carr, G.; Potter, R.B.; Nortcliff, S. Water reuse for irrigation in Jordan: Perceptions of water quality among farmers. Agric. Water Manag. 2011, 98, 847-854. [CrossRef]

38. Scott, C.A.; El-Naser, H.; Hagan, R.E.; Hijazi, A. Facing Water Scarcity in Jordan Reuse, Demand Reduction, Energy, and Transboundary Approaches to Assure Future Water Supplies. Water Int. 2003, 28, $209-216$. [CrossRef]

39. The World Bank. Water Reuse in The Arab World, from Principle to Practice, A Summary of Proceedings, Expert Consultation Wastewater Management in the Arab World 22-24 May 2011; The World Bank: Dubai, UAE, 2011.

40. Hussain, M.I.; Muscolo, A.; Farooq, M.; Ahmad, W. Sustainable use and management of non-conventional water resources for rehabilitation of marginal lands in arid and semiarid environments. Agric. Water Manag. 2019, 221, 462-476. [CrossRef]

41. Mateo-Sagasta, J.; Medlicott, K.; Qadir, M.; Raschid-Sally, L.; Drechsel, P.; Liebe, J. UN-Water Project on the Safe Use of Wastewater in Agriculture; Jens Liebe, J., Ardakanian, K., Eds.; UN: Now York, NY, USA, 2013.

42. Hussein, I.; Abu-Sharar, T.M.; Al-Jayyousi, O. The use of treated wastewater for irrigation in Jordan: Opportunities and constraints. Chart. Inst. Water Environ. J. 2003, 17, 232-238.

43. Qadir, M.; Bahri, A.; Sato, T.; Al-Karadsheh, E. Wastewater production, treatment, and irrigation in Middle East and North Africa. Irrig. Drain. Syst. 2010, 24, 37-51. [CrossRef]

44. Maldonado, P.M.A. Water Resources Assessment under Semi-arid Conditions-Modelling Applications in a Complex Surface-groundwater System in Jordan. Ph.D. Thesis, KIT-Bibliothek, Karlsruhe, Germany, 2017.

45. Mohsen, M.; Jaber, J.O. Potential of industrial wastewater reuse. Desalination 2002, 152, 281-289. [CrossRef]

46. Schyns, J.F.; Hamaideh, A.; Hoekstra, A.Y.; Mekonnen, M.M.; Schyns, M. Mitigating the risk of extreme water scarcity and dependency: The case of Jordan. Water 2015, 7, 5705-5730. [CrossRef]

47. SIWI: World Water Week. Water and Waste: Reduce and Reuse; SIWI: Stockholm, Sweden, 2017.

48. Pintilie, L.; Torres, C.M.; Teodosiu, C.; Castells, F. Urban wastewater reclamation for industrial reuse: An LCA case study. J. Clean. Prod. 2016, 139,1-14. [CrossRef]

49. Lyu, S.; Chen, W.; Zhang, W.; Fan, Y.; Jiao, W. Wastewater reclamation and reuse in China: Opportunities and challenges. J. Environ. Sci. 2016, 39, 86-96. [CrossRef]

50. Mo, W.; Zhang, Q. Energy-nutrients-water-nexus: Integrated resource recovery in municipal wastewater treatment plants. J. Environ. Manag. 2013, 127, 255-267. [CrossRef]

51. Husnain, T.; Liu, Y.; Riffat, R.; Mi, B. Integration of forward osmosis and membrane distillation for sustainable wastewater reuse. Sep. Purif. Technol. 2015, 156, 424-431. [CrossRef]

52. Geissen, V.; Mol, H.; Klumpp, E.; Umlauf, G.; Nadal, M.; van der Ploeg, M.; van de Zee, S.E.A.T.M.; Ritsema, C.J. Emerging pollutants in the environment: A challenge for water resource management. Int. Soil Water Conserv. Res. 2015, 3, 57-65. [CrossRef]

53. USAID. National Strategic Wastewater Master Plan for Jordan; USAID-ISSP: Washington, DC, USA, 2013.

54. Hussein, $\mathrm{H}$. Tomatoes, tribes, bananas, and businessmen: An analysis of the shadow state and of the politics of water in Jordan. Environ. Sci. Policy 2018, 84, 170-176. [CrossRef]

55. Water Authority of Jordan. Groundwater Basins Directorate Open Files; Water Authority of Jordan: Amman, Jordan, 2016.

56. Tong, L.; Liu, X.; Liu, X.; Zengwei, Y.; Zhang, Q. Life cycle assessment of water reuse systems in an industrial park. J. Environ. Manag. 2013, 129, 471-478. [CrossRef]

57. Chang, D.; Ma, Z. Wastewater reclamation and reuse in Beijing: Influence factors and policy implications. Desalination 2012, 297, 72-78. [CrossRef]

58. Yang, H.; Abbaspour, H.C. Analysis of wastewater reuse potential in Beijing. Desalination 2007, 212, $238-250$. [CrossRef] 
59. Smith, K.; Liu, S.; Hu, H.Y.; Dong, X.; Wen, X. Water and energy recovery: The future of wastewater in China. Sci. Total Environ. 2018, 637, 1466-1470. [CrossRef]

60. Li, Y.; Xiong, W.; Zhang, W.; Wang, C.; Wang, P. Life cycle assessment of water supply alternatives in water-receiving areas of the South-to-NorthWater Diversion Project in China. Water Res. 2016, 89, 9-19. [CrossRef]

61. Anne DE PAZZIS. As Samra Wastewater Treatment Plant A Major Asset for Sustainability in Jordan. Presented at the Stockholm World Water Week, Stockholm, Sweden, 31 August 2017.

62. SAMRA WASTEWATER TREATMENT PLANT JORDAN. Available online: http://www.fogevaporator.com/ pdf/samra-wastewater-treatment-plant.pdf (accessed on 18 November 2019).

63. McCarty, P.L.; Bae, J.; Kim, J. Domestic wastewater treatment as a net energy producer-can this be achieved? Environ. Sci. Technol. 2011, 45, 7100-7106. [CrossRef]

64. Saidan, M.; Khasawneh, H.J.; Aboelnga, H.; Meric, S.; Kalavrouziotis, I.; Hayek, B.O.; Al-Momany, S.; Al Malla, M.; Porro, J.C. Baseline carbon emission assessment in water utilities in Jordan using ECAM tool. Baseline carbon emission assessment in water utilities in Jordan using ECAM tool. J. Water Supply Res. Technol. 2019, 68, 460-473. [CrossRef]

65. Mehariya, S.; Patel, A.K.; Obulisamy, P.K.; Punniyakotti, E.; Wong, J.W.C. Co-digestion of food waste and sewage sludge for methane production: Current status and perspective. Bioresour. Technol. 2018, 265, 519-531. [CrossRef] [PubMed]

66. Agyeman, F.O.; Tao, W. Anaerobic co-digestion of food waste and dairy manure: Effects of food waste particle size and organic loading rate. J. Environ. Manag. 2014, 133, 268-274. [CrossRef]

67. Appels, L.; Lauwers, J.; Degrève, J.; Helsen, L.; Lievens, B.; Willems, K.; Van Impe, J.; Dewil, R. Anaerobic digestion in global bio-energy production: Potential and research challenges. Renew. Sustain. Energy Rev. 2011, 15, 4295-4301. [CrossRef]

68. Awasthi, M.K.; Pandey, A.K.; Bundela, P.S.; Wong, J.W.C.; Li, R.; Zhang, Z. Co-composting of gelatin industry sludge combined with organic fraction of municipal solid waste and poultry waste employing zeolite mixed with enriched nitrifying bacterial consortium. Bioresour. Technol. 2016, 213, 181-189. [CrossRef] [PubMed]

69. Chiu, S.L.H.; Lo, I.M.C. Reviewing the anaerobic digestion and co-digestion process of food waste from the perspectives on biogas production performance and environmental impacts. Environ. Sci. Pollut. Res. 2016, 23, 24435-24450. [CrossRef]

70. Al-Addous, M.; Saidan, M.N.; Bdour, M.; Alnaief, M. Evaluation of Biogas Production from the Co-Digestion of Municipal Food Waste and Wastewater Sludge at Refugee Camps Using an Automated Methane Potential Test System. Energies 2019, 12, 32. [CrossRef]

71. Dai, X.; Li, X.; Zhang, D.; Chen, Y.; Dai, L. Simultaneous enhancement of methane production and methane content in biogas from waste activated sludge and perennial ryegrass anaerobic co-digestion: The effects of $\mathrm{pH}$ and C/N ratio. Bioresour. Technol. 2016, 216, 323-330. [CrossRef]

72. Wan, J.; Gu, J.; Zhao, Q.; Liu, Y. COD capture: A feasible option towards energy self sufficient domestic wastewater treatment. Sci. Rep. 2016, 6, 25054. [CrossRef]

73. Gu, Y.; Li, Y.; Li, X.; Luo, P.; Wang, H.; Robinson, Z.P.; Wang, X.; Wu, J.; Li, F. The feasibility and challenges of energy self-sufficient wastewater treatment plants. Appl. Energy 2017, 204, 1463-1475. [CrossRef]

74. Hagos, K.; Zong, J.; Li, D.; Liu, C.; Lu, X. Anaerobic co-digestion process for biogas production: Progress, challenges and perspectives. Renew. Sustain. Energy Rev. 2017, 76, 1485-1496. [CrossRef]

75. Ronteltap, M.; Maurer, M.; Gujer, W. The behaviour of pharmaceuticals and heavy metals during struvite precipitation in urine. Water Res. 2007, 41, 1859-1868. [CrossRef] [PubMed]

76. Uysal, A.; Yilmazel, Y.D.; Demirer, G. The determination of fertilizer quality of the formed struvite from effluent of a sewage sludge anaerobic digester. J. Hazard. Mater. 2010, 181, 248-254. [CrossRef]

77. Antakyali, D.; Kuch, B.; Preyl, V.; Steinmetz, H. Effect of Micropollutants in Wastewater on Recovered Struvite, Proc. Water Environ. Fed. Nutr. Recovery Manag. 2011, 1, 575-582. [CrossRef]

78. Jabr, G.; Saidan, M.; Al-Hmoud, N. Phosphorus Recovery by Struvite Formation from Al Samra Municipal Wastewater Treatment Plant in Jordan. Desalin. Water Treat. 2019. [CrossRef]

79. EPA. Guidelines for Water Reuse, U.S.; Environmental Protection Agency: Washington, DC, USA, 2004.

80. Saidan, M.N.; Al-Yazjeen, H.; Abdalla, A.; Khasawneh, H.J.; Al-Naimat, H.; Al Alami, N.; Adawy, M.; Jaber, M.S.; Sowan, N. Assessment of on-site treatment process of institutional building's wastewater. Processes 2018, 6, 26. [CrossRef] 
81. Bixio, D.; Wintgens, T. Water Reuse System Management-Manual AQUAREC. Directorate-General for Research; European Commission: Brussels, Belgium, 2006.

82. Huber, M.M.; Gobel, A.; Joss, A.; Hermann, N.; Loffler, D.; McArdell, C.S.; Ried, A.; Siegrist, H.; Ternes, T.A.; von Gunten, U. Oxidation of pharmaceuticals during ozonation of municipal wastewater effluents: A pilot study. Environ. Sci. Technol. 2005, 39, 4290-4299. [CrossRef] [PubMed]

83. Feigin, A.; Ravina, I.; Shalhevet, J. Irrigation with Treated Sewage Effluent, 1st ed.; Springer: Berlin/Heidelberg, Germany, 1991.

84. Brissaud, F. Low technology systems for wastewater treatment: Perspectives. Water Sci. Technol. 2007, 55, 1-9. [CrossRef] [PubMed]

85. Ghermandi, A.; Bixio, D.; Traverso, P.; Cersosimo, I.; Thoeye, C. The removal of pathogens in surface-flow constructed wetlands and its implications for water reuse. Water Sci. Technol. 2007, 56, 207-216. [CrossRef] [PubMed]

86. Oron, G.; Gillerman, L.; Buriakovsky, N.; Bick, A.; Gargir, M.; Dolan, Y.; Manor, Y.; Katz, L.; Hagin, J. Membrane technology for advanced wastewater reclamation for sustainable agriculture production. Desalination 2008, 218, 170-180. [CrossRef]

87. Hyun, K.S.; Lee, S.J. Biofilm/membrane filtration for reclamation and reuse of rural wastewaters. Water Sci. Technol. 2009, 59, 2145-2152. [CrossRef]

88. Xu, P.; Drewes, J.E.; Bellona, C.; Amy, G.; Kim, T.U.; Adam, M.; Heberer, T. Rejection of emerging organic micropollutants in nanofiltration-reverse osmosis membrane applications. Water Environ. Res. 2005, 77, 40-48. [CrossRef] [PubMed]

89. Norton-Brandao, D.; Scherrenberg, S.M.; van Lier, J.B. Reclamation of used urban waters for irrigation purposes-A review of treatment technologies. J. Environ. Manag. 2013, 122, 85-98. [CrossRef] [PubMed]

90. Cano, A.; Cañizares, P.; Barrera, C.; Sáez, C.; Rodrigo, M.A. Use of low current densities in electrolyses with conductive-diamond electrochemical e oxidation to disinfect treated wastewaters for reuse. Electrochem. Commun. 2011, 13, 1268-1270. [CrossRef]

91. Wei, X.Z.; Gu, P.; Zhang, G.H. Research progress in the new model of pollutants in water and their removing methods. Ind. Water Treat. 2014, 34, 8-12.

92. Bernabeu, A.; Vercher, R.F.; Santos-Juanes, L.; Simon, P.J.; Lardin, C.; Martinez, M.A.; Vicente, J.A.; Gonzalez, R.; llosa, C.; Arques, A.; et al. Solar photocatalysis as a tertiary treatment to remove emerging pollutants from wastewater treatment plant effluents. Catal. Today 2011, 161, 235-240. [CrossRef]

93. Pedrero, F.; Albuquerque, A.; Amado, L.; Marecos do Monte, H.; Alarcón, J. Analysis of the reclamation treatment capability of a constructed wetland for reuse. Water Pract. Technol. 2011, 6, wpt2011050. [CrossRef]

94. Cirelli, G.L.; Consoli, S.; Di Grande, V. Long-term storage of reclaimed water: The case studies in Sicily (Italy). Desalination 2008, 218, 62-73. [CrossRef]

95. Yi, L.; Jiao, W.; Chen, X.; Chen, W. An overview of reclaimed water reuse in China. J. Environ. Sci. 2011, 23, 1585-1593. [CrossRef]

96. Waterwise Queensland. Manual for Recycled Water Agreements in Queensland. The State of Queensland. Environmental Protection Agency. 2005. Available online: http://www.epa.qld.gov.au/waterrecyclingagreement (accessed on 12 November 2019).

97. COAG. Communique August; Council of Australian Governments: Canberra, Australia, 2003.

98. Di Carlo, A.; Sherman, A. The Reclaimed Water Agreement Manual, Russell Kennedy Solicitors, Melbourne. 2004. Available online: http://www.clw.csiro.au/priorities/urban/awcrrp/stage1files/AWCRRP_8\%20Final_ 27Apr2004.pdf (accessed on 12 November 2019).

99. Moore, W.; Gould, J. Shoalhaven Reclaimed Water Management Scheme-How a small region built a large water recycling scheme. In Proceedings of the Water Recycling Australia, 2nd National Conference, Brisbane, Australia, 1-2 September 2003.

(C) 2020 by the authors. Licensee MDPI, Basel, Switzerland. This article is an open access article distributed under the terms and conditions of the Creative Commons Attribution (CC BY) license (http://creativecommons.org/licenses/by/4.0/). 